doi: $10.18575 /$ msrs.sm.e.18.09 UDC: $616.12-008.315-071$ COBISS.RS-ID: 7318296

\title{
Surgical Treatment of the Left Ventricular Assist Device Drive Line Infection with Abscess Formation
}

\begin{abstract}
Specific left ventricular assist device infections are the leading cause of morbidity and second most common cause of death in patients who survive the first six months after implanting device, and also they are the most common cause of readmissions to hospital. The patient is a 63-year-old who received LVAD HeartMate II. The patient was readmitted to the hospital due to a driveline exit site infection and a developed abscess formation at $4 \mathrm{~cm}$ from the DL exit site. After reducing infection with antibiotics therapy, he was successfully operated by creating new exit site while removing the driveline from the infected region of the subcutaneous tissue. Repositioning of the driveline to a new exit site with mandatory removal of part of the driveline from the subcutaneous tissue in the region of infection, with extensive debridement of the wound is appropriate therapeutic option for patients with driveline infection.
\end{abstract}

Key words: drive line infection, LVAD, C shaped

(Scr Med 2018:49:57-60)

\section{Duško Terzic ${ }^{1}$, Emilija Nestorović, Svetozar Putnik ${ }^{1}$, Saša Kačar', Vladimir Jovičić', Ana Janjić, Miljko Ristić ${ }^{1}$}

${ }^{1}$ Department for Heart Transplant, LVAD and ECMO, Clinic for Cardiac Surgery,Clinical Center of Serbia

\section{Contact address:}

Duško Terzić,

Clinic for Cardiac Surgery, Clinical Center of Serbia

Street address: Koste Todorovića 8 11000 Belgrade, Serbia e-mail: terzic.dusko@gmail.com phone number: +381-66-830-1966

Submitted: February $1^{\text {st }}, 2018$ Accepted: February 18 ${ }^{\text {th }}, 2018$

\section{Introduction}

Specific LVAD infections, among which infections of driveline exit site as the most frequent, are the leading cause of morbidity and second most common cause of death in patients who survive the first six months after implanting the LVAD. LVAD infections are also the most common cause of readmissions to hospital. Given the specific clinical condition in terms of having a foreign body and the forming of bacterial or fungal biofilm that prevents an effective antibiotic therapy, the treatment of these infections is a serious therapeutic challenge. By developing surgical techniques for treating driveline exit site infections, it is possible to increase the survival rate and reduce morbidity in patients with the inserted
LVAD. ${ }^{1,2}$

\section{Case Report}

The patient in question is a 63-year-old who had the pump for mechanical circulatory support of left ventricular HeartMate II implanted ten months earlier as bridge to transplant. The patient was admitted to hospital due to a driveline exit site infection and a developed abscess formation at $4 \mathrm{~cm}$ from the DL exit site. On reception, the skin around the exit driveline was red, swollen, sensitive and painful, with purulent secretion. An abscess formation with the surrounding cellulitis was formed at 4 $\mathrm{cm}$ from the exit site DL. (Figure 1.) 
Figure 1. Drive-line Exit Site Infection and a Developed Abscess Formation

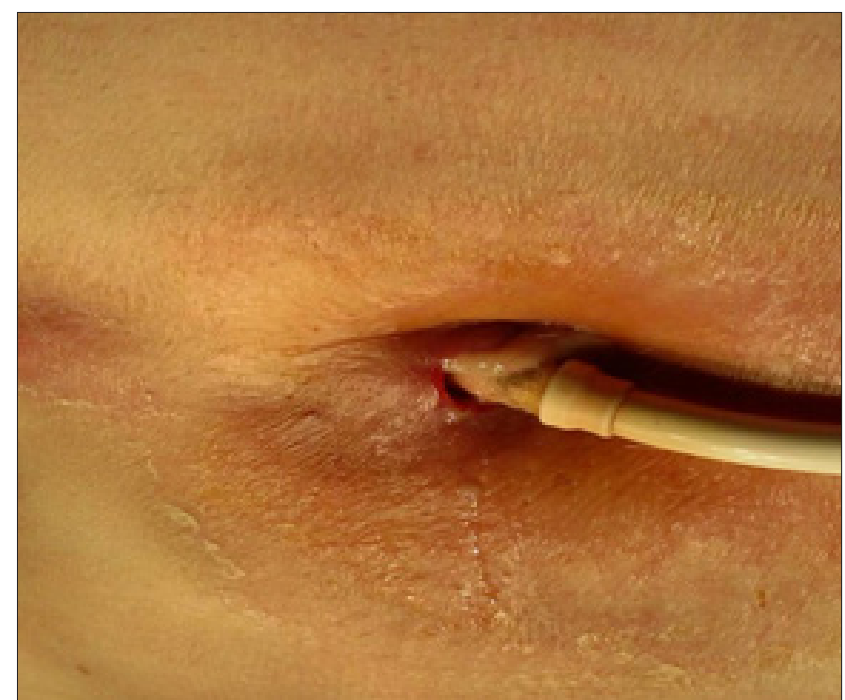

During the first hospitalization, when the pump HeartMate II was implanted, the operative and postoperative period passed regularly. In the operative procedure, the exit driveline was inserted through the skin in the "C shaped- doubled DL tunneling" form. At discharge from hospital, the skin around the driveline exit site healed well, with no signs of erythema, soreness, drainage, or other signs of infection.

Figure 2. P Repositing DL and Creating New Exit Site

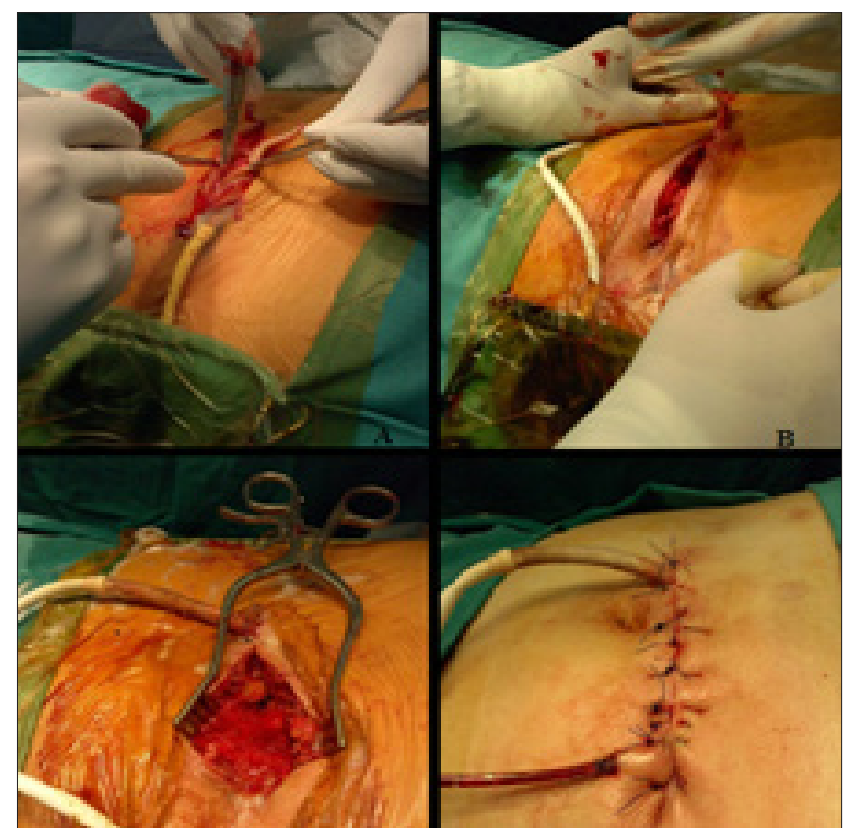

At hospital reception ten months after the implantation, the patient complained of burning and 'piercing' sensation in the driveline exit area with abscess formation $4 \mathrm{~cm}$ from DL exit site. Patient was without systemic signs of infection, blood stream tests were without bacteriological findings. Pseudomonas aeruginosa spp. was isolated from the swab taken around the driveline exit site of LVAD. Adequate antimicrobial therapy (Meropenem 3x1 g) was introduced according to antibiogram followed by intensive toilet of the wound three times a day.

On the eleventh day after the admission, after initial antibiotic therapy, the patient was operated. Incision in the driveline projection to a length of $8 \mathrm{~cm}$ was performed, part of the driveline outside subcutaneous structures was removed with an extensive debridement of the wound and abscess formation. Finally, the exit driveline was repositioned and fixed (without its returning to the subcutaneous adipose tissue), that is, a new exit site of DL was formed (Figure 2.). A swab was taken during the operation (which later confirmed Pseudomonas spp).

In the postoperative period, the patient was daily bandaged and adequate antibiotic therapy according to antibiogram was administered. The wound healed regularly. The stitches were removed on the twentieth postoperative day (Figure 3,a).

Figure 3 a,b,c. Wound Healing and Checkup

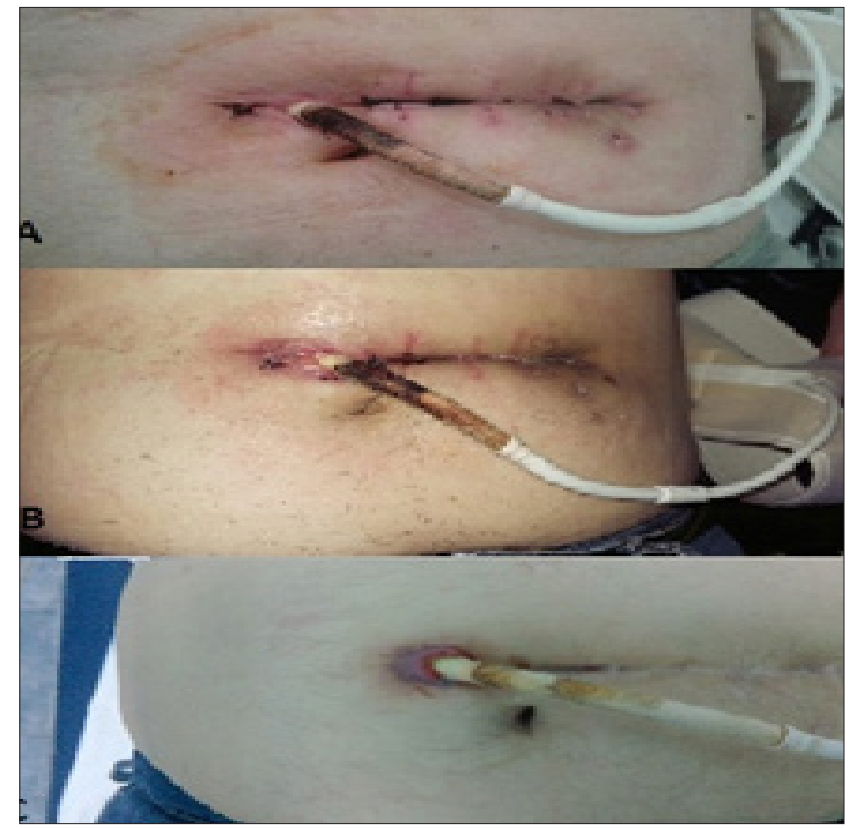

The patient was dismissed with the regularly healed wound, with no signs of erythema or soreness, and without secretion. A careful inspection of the outside of LVAD driveline showed no signs indicating disruption of the driveline's integrity. The checkup after three months (Figure 3,b), shows completely healed wound with no 
signs of infection. After one year, the checkup shows a small amount of granulation tissue around the exit site (Figure 3,c).

\section{Discussion}

High incidence of infectious syndromes in patients with implanted devices for mechanical circulatory support significantly affects the efficiency, increasing the rate of morbidity, mortality, length of hospitalization and treatment costs. Since there is a serious issue with the lack of donors, the necessity arises to develop various clinical modalities to treat DL infections in both BTT and DT group of patients. ${ }^{3}$

In the presented case, due to a specific DL infection in terms of the presence of a foreign body, constant irritation of the skin at the exit DL and consequent formation of bacterial biofilms by Pseudomonas spp., the use of antibiotics and frequent bandaging of the wound after the initial occurrence of the infection seven months after LVAD implant contributed to reduced symptoms (reduction of infection). However, a complete eradication of the infection has not been possible. ${ }^{4}$ In the given period, there were no adequate donors and the patient had met the requirements for heart transplant. Two months after discharge, the patients had recurrence of substantial secretion with an abscess formation at 4 $\mathrm{cm}$ from the DL exit site. Repeated antibiotic treatment partially alleviated symptoms after which the surgical treatment followed. The surgical treatment aimed to completely remove from the body a part of the driveline that was in infected region and reposition it to another spot. Removing the driveline from an infectious region included an extensive debridement of the wound. Antibiotic treatment was continued. DL primary placed in the form of $\mathrm{C}$ shaped- doubled DL tunneling, enabled the incision along the DL projection through the skin to be far enough from the infected area, as well as far enough from the mediastinum region. ${ }^{5}$ After hospital discharge, the patient is regularly bandaged once a day and ten months after there were no signs of an infectious process.

\section{Conclusion}

Repositioning of the driveline to a new exit site with mandatory removal of part of the driveline from the subcutaneous tissue that had previously been positioned in the region of infection, with extensive debridement of the wound can be an appropriate therapeutic option for patients with driveline exit site infection with or without possible abscess formations. Placing the driveline in the form of "C shaped" in the initial LVAD implant facilitates, this treatment provides wider opportunities and greater safety for patients.

\section{References}

1. Trachtenberg BH, Cordero-Reyes A, Elias B, et al. A review of infections in patients with left ventricular assist devices: prevention, diagnosis and management. Methodist DebakeyCardiovasc J 2015;11:28-32.

https://doi.org/10.14797/mdcj-11-1-28

PMid:25793027

PMCid:PMC4362062

2. Topkara VK, Kondareddy S, Malik F, et al. Infectious complications in patients with left ventricular assist device: Etiology and outcomes in the continuous-flow era. Ann ThoracSurg 2010; 90: 1270-1277.

https://doi.org/10.1016/j.athoracsur.2010.04.093 PMid:20868826

3. Koval CE, Thuita L, Moazami N, et al. Evolution and impact of drive-line infection in a large cohort of continuousflow ventricular assist device recipients. J Heart Lung Transplant 2014;33:1164-72.

https://doi.org/10.1016/j.healun.2014.05.011 PMid:25034793

4. Padera RF. Infection in ventricular assist devices: the role of biofilm. Cardiovasc Pathol. 2006 Sep-Oct;15(5):26470 .

https://doi.org/10.1016/j.carpath.2006.04.008 PMid:16979033

5. Fleissner F, Avsar M, Malehsa D, Strueber M, Haverich A, Schmitto JD. Reduction of driveline infections through doubled driveline tunneling of left ventricular assist devices. Artif Organs. 2013 Jan;37(1):102-7. https://doi.org/10.1111/aor.12036 PMid:23305580 


\section{Hirurško liječenje infekcije sa apscesnom formacijom izlaznog mjesta kabla za napajanje uređaja za potporu rada lijeve komore}

\section{SAŽETAK}

LVAD specifične infekcije, a među njima infekcije izlaznog mesta kabla kao najfrekventnije, predstavljaju vodeći uzrok morbiditeta i drugi najčešći uzrok smrti kod bolesnika koji prežive prvih šest meseci od ugradnje uređaja, a takođe su i najčešći uzrok ponovnih prijema u bolnicu. Naš pacijent je 63-godišnjak kojem je implantirana pumpa za mehaničku potporu cirkulacije leve komore HeartMate II. Pacijent je ponovo primljen u bolnicu zbog infekcije izlaznog mesta kabla LVAD-a i razvoja apscesne formacije na $4 \mathrm{~cm}$ od izlaznog mesta kabla za napajanje. Nakon redukcije infekcije antibiotskom terapijom, pacijent je uspješno operisan kreiranjem novog izlaznog mjesta i otklanjanjem izlaznog kabla iz inficiranog područja subkutanog tkiva. Repozicija kabla na novo izlazno mesto uz obavezno uklanjanje dijela kabla za napajanje potkožnog tkiva koji je prethodno bio pozicioniran u infektivnoj regiji, sa opsežnim debridmanom rane, a može biti adekvatan terapijski izbor kod bolesnika sa infekcijom izlaznog mjesta kabla za napajanje.

Ključne riječi: infekcija izlaznog kabla za napajanje, LVAD, C shaped forma 